\title{
"Trazados de edificios moros": graffiti medievales en los subterráneos de la torre de Comares de La Alhambra
}

\author{
Jose Ignacio Barrera Maturana *
}

En memoria de mi padre

\begin{abstract}
RESUMEN
En este trabajo presentamos el estudio de una serie de graffiti medievales existentes en los subterráneos de la Torre de Comares. Constituye un primer paso en la investigación de este tipo de manifestaciones localizadas en distintos espacios del Conjunto Monumental de la Alhambra y Generalife. El estudio de los mismos, nos hace pensar que los autores de los graffiti son auténticos alarifes participantes en las obras que en la primera mitad del siglo XIV se realizaban en esta zona de los palacios nazaríes. Un personal cualificado y conocedor de técnicas de geometría aplicables a la arquitectura, en el diseño de plantas y alzados de edificios. Así mismo y por las características que ofrecen los motivos representados, planteamos la doble hipótesis de que fueron operarios cristianos (cautivos o no) participantes en las obras, los autores de estos graffiti o quizá alarifes musulmanes a la manera de los cristianos.
\end{abstract}

PALABRAS CLAVE: Torre nazarí, graffiti, diseños geométricos, alarifes, musulmanes, cristianos.

Con estas palabras, hacía referencia Manuel Gómez-Moreno González a una serie de graffiti que a finales del siglo XIX pudo ver en los subterráneos de la Torre de Comares. Esta frase forma parte de una serie de anotaciones marginales efectuadas en tres ejemplares de su Guía de Granada (GÓMEZ-MORENO, 1892, T.ll: 28,46), destinadas a una segunda edición revisada que no llegó nunca a realizarse. Merece pues la pena recordar dos de aquellas anota-

\begin{abstract}
We intend to present, through this work, a study of several medieval graffiti found in the underground of "Torre de Comares". This is a first step at the research of this kind of signs located at different places at the Alhambra and Generalife. Its study suggest that the graffiti's authors are real master-builder participating in many works done at this same place at the "Palacios Nazaríes", during the first half of the XIV Century. A qualified staff who highly know about geometric applicable to the Architecture, floor design and about buildings elevation as well. Based on the motifs of the graffiti, we suggest a double theory about its authors, they could be Christian workers (captive or free) who participate at this work, or maybe they were Muslim master-builders working in the manner of the Christian, as well.
\end{abstract}

KEY WORDS: Nazarí tower, graffiti, geometric designs, master-builder, Muslims, Christians.

ciones, que en resumidas cuentas, son el origen de este trabajo:

"La torre de Comares ha sustituido a otra que ha quedado dentro de ella, tenía 7,10 m. de ancha y 7,34 de saliente. Al levantar los enlucidos de la parte baja de la torre se han descubierto las paredes de la primitiva y el adarve del cual se conservan el arranque de una almena y algunos escalones que bajaban al adarve por la parte del ángulo NE."

* nbarrema@hotmail.com 
"Fue adarve de la Torre que Abul Hachach engastó en la de Comares, al hacer nuevas edificaciones. La pared de aquella torre tiene 7,34 m. y en ella se observan trazados de edificios moros ejecutados en el enlucido con una punta acerada, enfrente ábrense tres habitaciones, donde probablemente estaría la guardia encargada de vigilar esta parte".

Aunque desde antiguo se recogen en la bibliografía algunas referencias a la existencia en la Alhambra de este tipo de manifestaciones, de época medieval y post-medieval, hasta el momento no se ha efectuado un estudio detenido de las mismas, en contraposición a los realizados en otros conjuntos monumentales o yacimientos arqueológicos hispanomusulmanes, como por ejemplo en Madinat al-Zahra (Córdoba) (BARRERA, CRESSIER y MOLINA, 1999; BARRERA, en prensa), en la Sierra de los Filabres (Almería) (CRESSIER, 1986; BARRERA y CRESSIER, 2003), en las rábitas califales de las dunas de Guardamar del Segura (Alicante) (BARCELÓ, 1989; RUBIERA, 2004) y en la ciudad califal de Vascos (Navalmoralejo, Toledo) (IZQUIERDO, 1994).

De entre aquellas referencias bibliográficas de graffiti en la Alhambra, podemos destacar, además del caso que nos ocupa, la existencia de una serie de letras árabes incisas en el yeso endurecido que sustenta las pinturas sobre cuero de la Sala de los Reyes (CONTRERAS, 1878: 258-260); "letreros árabes y cristianos arañados sobre el enlucido" aparecen en algunos arcos del muro occidental del Patio de la Acequia en el Generalife (GÓMEZ-MORENO, I 892, T.l: 168, 169); una inscripción que reza "lunes a 26 de octubre años | 56 | años", fue localizada por Leopoldo Torres Balbás en uno de los arcos de la galería norte del Patio de Machuca (VÍLCHEZ, 1988: 107,1 16); en el reverso de una de las piezas de madera que forman el majestuoso techo del Salón de Comares, aparecieron escritas algunas anotaciones de los artesanos participantes en la obra (CABANE-
LAS, 1988), por último círculos concéntricos incisos y trazados a compás, se localizaron en la cúpula de la Puerta de las Armas (RODRIGO y CALANCHA, 1990: Ims. 30,31).

Así pues, y a pesar de ser conscientes del tiempo transcurrido desde aquellas breves anotaciones de Gómez-Moreno González, decidimos solicitar al Patronato de la Alhambra y Generalife ' el acceso (además de a otros espacios) a los subterráneos de la Torre de Comares para comprobar si aún se conservaban los referidos motivos y poder llevar a cabo el estudio de los mismos, tal y como hicimos anteriormente con otros existentes en la muralla nazarí del Albayzín (BARRERA, 2002; BARRERA, 2003; BARRERA, 2004), igualmente descubiertos por aquel ilustre investigador.

Tras varias visitas a los subterráneos de la Torre de Comares, pudimos localizar aquellos desconocidos graffiti y comprobar el buen estado de conservación en que se hallaban. Tomamos medidas de su ubicación, fotografías y llevamos a cabo el calco directo de los motivos, utilizando para ello película plástica transparente y rotuladores de tinta permanente. Posteriormente procedimos a su reproducción sobre papel vegetal, precisando los trazos con la ayuda de fotografías tanto de detalle como de conjunto.

Constituyen por tanto estas líneas, los primeros resultados de un estudio más amplio que pretendemos llevar a cabo sobre este tipo de manifestaciones, en distintos espacios del Conjunto Monumental de la Alhambra y Generalife.

\section{LOCALIZACIÓN DE LOS GRAFFITI}

Como hemos podido ver más arriba, Gómez-Moreno González sitúa los graffiti que tratamos en la pared exterior de una antigua torre que quedó engastada en la actual de

\footnotetext{
I Agradecemos al Patronato todas las facilidades ofrecidas para poder acceder a los espacios solicitados, así como a su personal por la amabilidad mostrada.
} 
Comares en tiempos de Yúsuf I (I 333- | 354), y que puede verse desde el adarve que la atraviesa.

La bibliografía tradicional ha tratado desde antiguo estos subterráneos, ofreciendo interesantes descripciones de ellos y de algunas de las intervenciones y remodelaciones sufridas a lo largo del tiempo. Entre ellas destacan las obras realizadas en el siglo XVII y las efectuadas por Torres Balbás (CASARES, 1973; VÍLCHEZ, 1988: 218,219):

"Los sótanos de la Torre de Comares del siglo XIII se habían macizado en el siglo XVII debido a los problemas de estabilidad que planteaba la torre a partir de la explosión del polvorín de San Pedro en 1500, como hemos descrito ampliamente al hablar de la parte alta de la Torre de Comares. En junio y julio de 1925 se empiezan a vaciar estas habitaciones que se habían macizado de sillares..."

"En la misma fecha se cierra la comunicación con el adarve y sótanos de la torre del siglo XIV que se había abierto en las obras del siglo XVII.

El relleno de las habitaciones sigue vaciándose en febrero de 1933..."

"Toda la zona de adarves y sótanos de la torre del siglo XIV se realizaron en bloque a partir del 5 de enero de 1925."

"Las tres habitaciones que forman los sótanos habían sido ya reparadas por Modesto Cendoya que las recalza en enero de 1910, y las sola en Abril de 19/2."

También Manuel Gómez-Moreno Martínez (GÓMEZ-MORENO, 1966: 39) nos dice lo siguiente sobre este espacio:

"Cabe la sospecha de que la primitiva Torre de Comares, que consta era más pequeña que la actual, y la Sala de la Barca, que era asimismo más corta, correspondiesen al palacio de Ismail, con su baño adjunto que, modificado por Yúsuf, es la parte más antigua del palacio actual."

Poco después, Basilio Pavón Maldonado (PAVÓN, 1975: 67) describe de este modo la zona que nos ocupa:
"Yusuf la levanta (se refiere a la Torre de Comares) como punto principal de referencia de su nuevo palacio, la construye donde estuvo otra más diminuta que es probable existiera ya en los últimos años del siglo XIII.

La torre forma en planta un rectángulo de 7,50 m. $\times 5.50 \mathrm{~m}$. dispuesta en sentido apaisado, como la mayoría de las torres del siglo XIII. Exteriormente iba pintada con almagra; su enrojecida fachada exterior puede verse hoy desde el adarve que atraviesa la torre grande de Comares. Fabricada con hormigón, el interior se divide en tres naves; es muy probable que tuviera cuatro pilares, con sus respectivas responsiones, con lo que la planta alcanzaría nueve tramos, como el aljibe árabe que subsiste por bajo del Palacio de Carlos V."'

Ma José de la Torre López (TORRE, 1995: 195197; GONZÁLEZ y CASAS, 1997) en un estudio realizado sobre los materiales de la Alhambra (tapiales, revocos, enlucidos...), apunta:

"Ya se habló de que en los sótanos de Comares hay restos de fábricas diferentes. Una de ellas es un tapial calicostrado muy bien construido y cubierto por un fino revoco de cal blanca. Este hecho ya resulta extraño, ya que lo normal es que en interiores sólo haya revocos de yeso. Otro hecho llamativo es que en el resto de la Torre y Palacio de Comares el tapial es de arcilla y cal, pero no calicostrado. Podemos considerar pues esta fábrica como diferente de la del Palacio de Comares y anterior a él. Este tipo de fábrica se repite exactamente en otro punto: el sótano que tiene acceso desde el Patio de la Reja. Si se unen los puntos de fábrica similar podemos obtener un perfil de lo que se conserva bajo Comares de una construcción anterior, con toda probabilidad el Alcázar de Ismail".

Más recientemente Manuel Gómez-Moreno Calera (GÓMEZ-MORENO, 2002: I31) nos dice:

"En el siglo XIV, los hitos cronológicos identificados más importantes serían: la construcción de la Puerta de las Armas y de la Tahona por Ismail I y la muralla que las enlaza hasta la torre Muhammad, además de una torre y lienzos que se identifican bajo el palacio actual de Comares...". 
Pero tras recientes estudios surgen nuevas opiniones, como son las de Antonio Malpica Cuello en relación a la ubicación del palacio de Ismail I (1313-1324):

"El llamado alcázar de Ismail no parece tan claro que estuviese debajo de Comares. Igualmente podía pensarse que se encontrase en el espacio en el que hoy se levanta Leones, pues su muro meridional esta alineado con la calle Real Baja y con el eje de la rawda, siendo ésta creación del mencionado monarca según todos los indicios" (MALPICA, 200 I: 60);

"También se reconoce en la parte meridional de la planta del palacio de los Leones un descuadre, señal inequívoca de que se quisiera respetar construcciones precedentes. Seguramente la qubba, pero también el aljibe en el lado opuesto de ésta" (MALPICA, 2002a: 197).

"Nos atreveríamos a decir que en lo esencial Ismail I debió dejar diseñada la zona palatina y los edificios anejos. La organización de los palacios, especialmente el de Comares, con la torre pegada a la muralla y en el lado menor del rectángulo, responde, según creemos, a la necesidad de articular el espacio globalmente" (MALPICA, 2002b: 35).

En espera de que la discusión científica continúe y se realice una investigación a fondo sobre la ubicación del supuesto palacio de Ismail I, sí parece que podamos aceptar como punto de partida, que los graffiti que descubrió en su día Gómez-Moreno González, aparecen incisos en la fachada exterior de una torre rectangular de tapial calicastrado cubierto con un fino revoco de cal blanca, anterior a la actual Torre de Comares, existente para unos autores ya a finales del siglo XIII y levantada para otros en tiempos de Ismail $\mathrm{I}$.

Efectivamente, en nuestras visitas al adarve que atraviesa la Torre de Comares de Oeste a Este, localizamos los graffiti situados en la pared sur del mismo, sobre la fachada exterior de esa antigua torre, claramente distinguible por su fábrica (Lám. I). Tomamos medidas de la torre que coincidieron con las ofrecidas por Pavón Maldonado, es decir 7,50 m. frente a las aportadas por Gómez-Moreno González.
Los motivos descubiertos se distribuyen de la siguiente manera: un primer grupo, que denominaremos desde ahora Conjunto $A$, se localiza a 5,80 m. de distancia del umbral de acceso al adarve por el Oeste, $y$ un segundo grupo - Conjunto B a 5,20 m. del umbral Este. Los motivos conservados del Conjunto A se sitúan a $1,28 \mathrm{~m}$. del actual nivel del suelo y alcanzan una altura máxima de $2 \mathrm{~m}$. Los del Conjunto $B$, se desarrollan entre los $1,18 \mathrm{~m}$. y los 2,36 m., prácticamente en contacto con el arranque de la bóveda de medio cañón que cubre el adarve. Entre ambos conjuntos se aprecia una fábrica moderna, que corresponde a las obras realizadas en 1925 por Torres Balbás para cerrar la comunicación que se había abierto en el siglo XVII (CASARES, 1973: 60), entre el adarve y los sótanos de la antigua torre (Fig. I)

\section{TÉCNICA DE EJECUCIÓN Y DESCRIPCIÓN DE LOS GRAFFITI}

Los graffiti están ejecutados mediante trazos incisos sobre el enlucido de la pared de la torre. Se detecta el empleo del compás de doble punta para el marcado de centros, el trazado de líneas curvas y círculos, aunque no descartamos la utilización de una de las puntas de este instrumento para el trazado de las líneas rectas.

Ya dijimos anteriormente que se hallaban en buen estado de conservación, aunque han desaparecido parcialmente, debido al desprendimiento del enlucido en las zonas más bajas. Así mismo, parte de ellos se ven afectados por una serie de muescas producidas por piquetazos, que podemos relacionar tal vez con obras realizadas en este espacio a fines del siglo XIX, según nos informa Gómez-Moreno González:

"Al levantar los enlucidos de la parte baja de la torre se han descubierto las paredes de la primitiva.....".

El Conjunto A, es decir el grupo de graffiti situado más cercano a la entrada de acceso al adarve por el Oeste (Fig.2), consiste en la representación de un total de siete arcos ligeramente 
apuntados. Seis de ellos forman tres parejas que se sitúan unas sobre otras, de manera que las dos primeras parejas se superponen parcialmente por sus extremos. Así mismo podemos comprobar que los arcos de la primera pareja se unen por sus trasdoses. Los dos arcos más bajos podemos definirlos como auténticos arcos de herradura apuntados, pudiéndose distinguir sus impostas. Sobre el arco más bajo de la izquierda, se superpone otro parcialmente conservado. Por último, algunos de los espacios vacíos se rellenan con un profuso rayado de líneas verticales. Se aprecia como dijimos arriba, la utilización del compás para el trazado de los arcos, círculos y marcado de centros.

Aunque a primera vista estos dibujos nos recuerdan a los arcos superpuestos de la Mezquita de Córdoba, y por tanto hablaríamos del alzado de un edificio, también es posible que se trate de la planta de un edificio (eso sí, carente de perspectiva) formado por dos naves abovedadas con arcos de herradura apuntados.

Pero lo más interesante de todo este conjunto, es que todos sus elementos aparecen inscritos en una cuadrícula de proporciones bastante irregulares, trazada a mano alzada mediante incisión.

Según podemos ver, primero se trazó la cuadrícula y a partir de ella los arcos, marcándose previamente los centros necesarios (se aprecian las improntas de las puntas del compás en las líneas de la cuadrícula) (Fig. 5a).

Para finalizar, existen conservadas parcialmente fuera de la cuadrícula y junto al arco más bajo situado a la derecha, una serie de circunferencias cuyos trazos se entrecruzan dando lugar en su interior al dibujo de rosetas de seis pétalos $^{2}$ (Fig.5d).

El Conjunto B (Fig.3), representa una enorme torre con doble arcada de gran tamaño en su frente y terraza almenada con arco más pequeño que los anteriores. Pueden verse matacanes, igualmente almenados, en sus esquinas. Todo el graffiti se realizó mediante incisión.

El cuerpo de la torre se rellena con líneas que dibujan un aparejo regular de grandes sillares. Los tres arcos existentes son de herradura apuntados, distinguiéndose en los que forman la arcada doble detalles interesantes como son sus impostas, albanegas sin decoración y dovelas simulando sillares de piedra. Entre los sillares situados por encima de los arcos y la terraza de la torre, existe un espacio vacío donde tan sólo se dibujan a todo lo ancho de la torre, dos líneas horizontales a modo de molduras.

En la terraza se pueden ver cinco merlones cuadrados rematados por triángulos. Dos de ellos forman el parapeto del matacán derecho y uno el del izquierdo, los dos merlones restantes se sitúan junto al pequeño arco de herradura existente en la terraza de la torre. Los matacanes situados en las esquinas aparecen volados sobre ménsulas (Fig.5c).

Nuevamente se utilizó una trama cuadriculada de líneas incisas para trazar tanto el pequeño arco de herradura situado en la terraza de la torre (que aparece desplazado hacia la izquierda), como los grandes arcos que componen la doble arcada. El marcado de centros y el trazado de los arcos se realizó a compás, pudiéndose ver las improntas de las puntas en las líneas incisas que conforman las cuadrículas.

Aunque la parte inferior del graffiti aparece afectado por el desprendimiento del enlucido, aún se puede ver parcialmente, un arco apuntado trazado a partir de otra trama cuadriculada, así como varios círculos concéntricos entrecruzados. Al igual que en los otros motivos descritos de este conjunto y en los del Conjunto A, la trama cuadriculada de líneas

2 Graffiti que representan rosetas similares y con diseños más elaborados, las hemos encontrado en varias casas moriscas del barrio del Albayzín, que son objeto de nuestro estudio en colaboración con el Laboratorio de Arqueología Medieval de la Escuela de Estudios Árabes de Granada (CSIC). 
incisas, se trazó a mano alzada y los motivos curvos y circulares a compás. También en este último motivo se aprecian las improntas de las puntas del compás (Fig.5e).

\section{INTERPRETACIÓN DE LOS MOTIVOS}

Es posible establecer cierto parentesco entre las técnicas de ejecución empleadas en el trazado de estos graffiti y las utilizadas en el dibujo de zócalos pintados y yeserías de época nazarí.

Recientemente se ha llevado a cabo el estudio de algunos zócalos pintados nazaríes de la Alhambra y de Granada (Sala de la Barca, Patio del Harén, Peinador Bajo y Cuarto Real de Santo Domingo), donde se detecta el trazado de un dibujo previo a la composición final de los zócalos, constituido por líneas de cordada, líneas curvas incisas y puntas de compás (Fig.4 y Lám.2) (GARCÍA, MEDINA y LÓPEZ, 2003: 18):

\begin{abstract}
"En cuanto al proceso de ejecución debemos decir que de forma general se aprecia una estructura de dibujo previo que sirve para encajar la composición. Esta trama, normalmente cuadrada, puede ser homogénea o no, pero siempre existe".
\end{abstract}

"Es constante el empleo de dibujo preparatorio de cordada para el trazado de la trama de base y de líneas incisas para situar los centros de las formas circulares y definir el tamaño de los motivos que presentan una simetría central; así mismo se debió emplear este sistema para el trazado de algunos elementos de la composición, círculos, lóbulos, octógonos, etc."

Nuestros graffiti como se puede apreciar, se ajustan a los pasos seguidos en la ejecución del dibujo preparatorio de los zócalos, aunque con una leve diferencia: la trama cuadrada de base ("homogénea o no") que existe dibujada en los zócalos, la hallamos en los graffiti de manera incisa y ofreciendo proporciones a veces muy irregulares, ya que su trazado se hizo a mano alzada, sin el empleo para ello de reglas o cuerdas (Fig.5b). Tramas de líneas incisas fueron utilizadas en zócalos de época almohade, es el caso del aparecido en el Palacio del
Yeso del Alcázar de Sevilla (VALLE y RESPALDIZA, 2000: 65,66) y también las vemos en las pinturas murales que decoran el baño mudéjar de doña Leonor de Guzmán en el Palacio de Tordesillas (Valladolid) (TORRES, 1959: 80), así como en yeserías de la Alhambra, en la casa nazarí de la calle Cobertizo de Santa Inés de Granada (RUIZ, 1996) y en la Torre de Gabia (Granada) (GARCÍA, 1987).

El diseño de motivos arquitectónicos insertos en una trama o cuadrícula, al igual que lo hacen los elementos decorativos de zócalos y yeserías, respondería a una norma de taller generalizada en distintos oficios como hemos podido ver.

Los graffiti objeto de nuestro estudio, podrían ser alzados y plantas de edificios ejecutados, como mandaba la tradición y las normas del oficio así lo indicaban, a partir de una trama cuadriculada, de manera que unos simples trazos eran suficientes para entenderse en el transcurso de una sencilla "lección de albañilería", donde la economía del trazo era la regla, y unas escasas líneas podían sugerir una doble arcada, un arco y sus impostas, un aparejo de sillares, etc.

Fruto también de estas explicaciones serían una serie de croquis realizados a tinta sobre varios cimacios de la Mezquita de Córdoba (SOUTO, 2003), que reproducen el diseño de celosías y de las bóvedas nervadas que cubren la maqsura de tiempos de al-Hakam II. Conocemos también el arco lobulado descubierto a principios del siglo $X X$ en Madinat al-Zahra (VELÁZQUEZ, I912: Im. XXIII, fs. 50,5।), otros graffiti con temas arquitectónicos que hemos tenido la oportunidad de estudiar en ese mismo conjunto arqueológico (BARRERA, CRESSIER y MOLINA, 1999: 56, 78, f.29; BARRERA, en prensa), así como los arcos localizados en la muraIla nazarí del Albayzín (Granada) (s. XIV) (BARRERA, 2002: 298-299, f.24, Im.I I; RUíz y PADIAL, 200 I), y en la iglesia gótico-mudéjar del Divino Salvador de Vejer de la Frontera (Cádiz) (ss. XIII-XIV) (ABELLÁN, I982: f.I) (Fig.6).

Nuestros graffiti serían rudimentarias representaciones (aunque en el momento de su ejecución, útiles herramientas explicativas) de esas 
plantas y alzados de edificios dibujados sobre papel o pergamino, que debieron existir en el medioevo andalusí.

Como ejemplos tempranos de esos escasos planos de arquitectura, conocemos plantas abatidas bidimensionales en una serie de Beatos mozárabes del siglo $X$, que representan a un edificio con torres exteriores y espacio central cuadrangular. Están emparentadas con las plantas cuadradas que ofrecen castillos tanto orientales como andalusíes de época omeya. En opinión de Álvaro Soler y Juan Zozaya, estos castillos andalusíes se construyeron según modelos orientales y siguiendo unos conocimientos transmitidos probablemente mediante "manuales de arquitectura militar", que incluirían alzados como el representado en un graffiti de Qasr al-Hayr al-Garbi (Siria) y plantas similares a las que aparecen en los códices mozárabes (SOLER y ZOZAYA, 1992).

A través de las miniaturas de las obras de Alfonso $X$ el Sabio y de las ilustraciones del álbum de Villard de Honnecourt, ambas del siglo XIII, nos acercamos a los conocimientos utilizados en la época, sobre técnicas de arquitectura gótica y mecánica, pudiéndose detectar en éstas, ciertos contactos con el mundo andalusí.

De finales del siglo $X V$ conocemos bocetos de Leonardo da Vinci donde se representan bóvedas nervadas hispanomusulmanas de similar diseño a los croquis, antes referidos, descubiertos por Juan Antonio Souto en la Mézquita de Córdoba (TORRES, 1952c).

Ya de fechas más tardías, en unos planos de arquitectura del siglo $X V I$, realizados sobre papel por un maestro uzbeco, aparecen insertas en cuadrículas las plantas de un edificio. Así mismo en una miniatura de ese mismo siglo, junto al rey mongol Babur se puede ver a un arquitecto que sujeta en sus manos un plano con diseño cuadriculado (RUÍZ, 1996: 32; GÁMIZ, 200I: 127, 128, 135).

Con respecto a la torre representada en el Conjunto $B$ y para una mejor comprensión de este graffiti, hemos intentado localizar los dis- tintos elementos arquitectónicos que contiene esta torre en una realidad cercana, realidad de la que formaba parte tanto el autor de los graffiti como el espacio donde se localizan los motivos, y que no es otra que la propia Alhambra.

Así por ejemplo, los arcos de sillería que forman la doble arcada de la torre recuerdan a la Puerta del Arrabal, atribuida por algunos autores a Muhammad III (I302-1309), e incluso a la grandes puertas de la Justicia o Siete Suelos construidas en tiempos de Yúsuf I, cuyos arcos de herradura apuntados se insertan en grandes frentes levantados con sillares regulares. También es cierto que, aunque trazados a una escala mayor, nos traen a la mente las numerosas ventanas gemelas con parteluz y arcos de herradura que podemos ver en distintas estancias de la Alhambra. Como elemento comparativo, resulta del mismo modo interesante el diseño que ofrece una losa de piedra expuesta en el Museo de la Alhambra, correspondiente a la cabecera de una sepultura fechada en los siglos XIII-XIV. Representa una torre con almenas triangulares y doble arcada tallada en su frente, probable alusión alegórica a las "puertas del paraíso" que debía de traspasar el difunto tras su muerte.

En relación al almenado que vemos en nuestro graffiti, el utilizado en las torres y murallas de la Alhambra, parece que originariamente era cuadrado, añadiéndose en el siglo XVI remates piramidales (GÓMEZ-MORENO, 1892 T.l: 45, I34; VIÑES, 1982: 88). Prácticamente no queda nada del almenado original, aunque se pueden localizar restos de algunos merlones en la torre que quedó engastada en la de Comares o en el muro sobre el que se levanta la Casa de Villoslada y la inmediata a saliente, en la zona del Partal (VÍLCHEZ, 1988: 320,335). Sobre el que tenía la Torre de la Vela, nos dice GómezMoreno Martínez (GÓMEZ-MORENO, 1966: I I):

"La plataforma superior fue privada de sus almenas en el siglo XVI; pero excavando alrededor de la torre han salido varias que desde arriba cayeron".

Otro tema interesante a tratar, es el de las estructuras voladas en la Alhambra. En ellas 
incluimos elementos como los ajimeces, saledizos y por supuesto matacanes. Parece ser que los balcones de la Torre de Comares tenían ajimeces según se representan en el escudo de la Casa de Castril, construida en 1539 por un nieto de Hernando de Zafra. También conocemos por Torres Balbás, que hubo saledizos u obras voladas en la zona de la Torre de Machuca (VÍLCHEZ, 1988: 109,1 17; TORRES, 1947):

"Halla Torres Balbás en el frente norte de la torre, al exterior, "cajas de haber sido empotradas gruesas vigas para sostener, sin duda, una obra volada; se conservan trozos de vigas dentro del muro»"

Pero son los matacanes que aparecen en nuestro graffiti, los elementos arquitectónicos volados que mayor interés despiertan, dada la enorme similitud que ofrecen con los que en su día hubo de tener en las esquinas la Torre de los Picos, de los cuales tan sólo se han conservado las ménsulas que los soportaban. Estas ménsulas voladas poseen un perfil casi idéntico a las del graffiti (Lám.3 y Fig.5c)

Tras este rastreo por los edificios de la Alhambra en busca de los diferentes elementos arquitectónicos que componen la torre de nuestro graffiti, podemos afirmar que la Torre de los Picos es el único edificio que contiene todos los elementos referidos. Hallamos la terraza almenada, las ménsulas que soportaban matacanes en las esquinas y en su planta alta ventanas labradas en piedra con molduras góticas, arcos de herradura con alfiz y parteluz, que se abren a una sala cubierta con bóveda de ojivas, decorada con pinturas (Láms.4, 5 y 6).

\section{AUTORÍA Y CRONOLOGÍA DE LOS GRAFFITI}

Después de todo lo dicho hasta ahora, y en especial acerca de la técnicas empleadas en la ejecución de los motivos, parece lógico pensar que el autor de estos graffiti sería una persona o grupo, diestra en el uso del compás y conocedora de ciertas técnicas de oficio empleadas también en la ejecución de zócalos y yeserías.
Estaríamos ante la presencia de un auténtico maestro o alarife (tal vez los 'Urafa' al-banna'in: alarifes de los albañiles, 'Urafa' al-muhandisin: alarifes de los geómetras, "maestros de tapiar" o "maestros de asentar cantos tajados", que se nombran en las fuentes escritas andalusíes y cristianas) (OCAÑA, 1986: 56-59; SOUTO, 1997; SOUTO, 200 I; MENÉNDEZ, 1986: 107, I I3; TORRES, 1952a), que con estos dibujos incisos en la pared, explicaba a sus compañeros, o se explicaba con ellos, de un modo rápido y sencillo, sobre la tarea de construir o de diseñar un espacio arquitectónico. Hablamos de aquella "lección de albañilería" a la que antes hacíamos alusión.

El hecho de que en la zona más alta de la pared donde se sitúa el graffiti, prácticamente en la línea de arranque de la bóveda de medio cañón que cubre el adarve, se trazara a compás a partir de una trama cuadriculada, el pequeño arco que corona la torre, nos indica que el autor del mismo se vio obligado a utilizar para su trazado, una escalera o andamio. Esta apreciación así como la técnica de ejecución empleada, nos hace suponer que el autor o autores de los graffiti, serían alarifes que participaron posiblemente en la construcción de esa antigua torre o en las nuevas obras que se efectuaron en la zona en tiempos de Yúsuf I. Descartamos por tanto, que los graffiti sean obra de miembros del servicio de palacio o del cuerpo de guardia que ocupaba los sótanos de la Torre de Comares.

Pero estos datos no son los únicos que nos ofrecen información sobre la autoría y cronología aproximada de los graffiti.

Si nos remitimos de nuevo a la torre representada en el graffiti y dado los numerosos detalles que ofrece, se podría decir que se trata de un tipo de torre que constituye el fiel reflejo de una realidad coetánea al autor o autores de los graffiti, bien conocida por estos y que posiblemente estaban acostumbrados a ver. Ya apuntamos anteriormente el gran parecido que mantiene con la Torre de los Picos de la Alhambra.

Torres Balbás ofreció ejemplos de torres cristianas con características similares a la de los 
Picos. Se refirió a la torre de El Carpio (Córdoba) de 1325, la torre del Homenaje del castillo de las Aguzaderas en El Coronil (Sevilla) terminada en I355, la torre del castillo de Alcalá de Guadaira (Sevilla) levantada en los últimos años de Alfonso XI o en el reinado de su hijo Pedro I, así como la torre del castillo de Cañete de las Torres (Córdoba), todas ellas con matacanes angulares (TORRES, 1952b). Es decir, un tipo de defensa vertical que se generaliza en España en el siglo XIV, aunque ya se detecta la existencia de matacanes sobre puertas en la segunda mitad del siglo XIII, según podemos ver en las ilustraciones de las Cantigas de Alfonso X (VILLENA, 1987: 310 ; MENÉNDEZ, 1986: 278,279).

Pavón Maldonado también compara los distintos elementos de inspiración cristiana de la Torre de los Picos con los existentes en palacios mudéjares de mediados del siglo XIV, como el de Tordesillas (Valladolid) construido por Alfonso Xl, el de Don Pedro en el Alcázar de Sevilla, en el que intervinieron artesanos nazaríes enviados desde Granada, y con otros motivos de la Capilla de San Bartolomé de Córdoba (PAVÓN, 1977: 132,133).

Para ambos autores la Torre de los Picos se levantó a mediados del siglo XIV sobre una torre anterior posiblemente del siglo XIII, con la participación de obreros cristianos, cedidos por Don Pedro I a Muhammad V (I 354-I 358 y I 36 I- 1390), serían los mismos artesanos que trabajaban en el Palacio de los Leones, en las pinturas sobre cuero de la Sala de los Reyes. Corroboran sus opiniones aludiendo a una noticia ofrecida por Ibn al-Jatib en la lhata, donde se dice que "obreros cristianos se encargaron, entre los años 1365 y | 366, de llevar a Castilla el cadáver del Infante Don Juan, muerto en 1319 en un combate de la Vega de Granada, después de estar algún tiempo sobre la puerta de ésta".

Quizás también haga alusión a la presencia de obreros cristianos en Granada, la casida sultaniyya de Ibn Zamrak del Patio de los Arrayanes, dedicada a Muhammad V: "De mañana si a un pueblo vas de infieles, eres dueño a la tarde de sus vidas. Con dogal de cautivos, tus palacios te levantan después, como albañiles". Con similar temática, en un poema de Ibn al-Yayyab de tiempos de Yúsuf l, ubicado en la Torre de la Cautiva y que habla de su construcción, podemos leer, "Honor de la fe ha sido el que, forzados cautivos de los elches, la elevaran" (GARCÍA, 1985: 93-95, 137, I38; RUBIERA, 1995: 100- 103).

Así mismo, en el estudio que llevamos a cabo de los graffiti existentes en la muralla nazarí del Albayzín (BARRERA, 2004), levantada también en tiempos de Yúsuf I, detectamos la participación en las obras de cautivos cristianos. Se localizaron inscripciones en letra castellana gótico-cursiva que recreaban documentos públicos de la época y hacían alusión a los cautivos y su mundo, así como figuras clásicas y simbólicas de la iconografía medieval cristiana, tales como motivos heráldicos, castillos, peces, perros, etc. Los castillos representados, al igual que el que ahora estudiamos, se dibujaban simulando aparejos regulares de grandes sillares, mostraban torres almenadas con merlones rematados por triángulos y a veces se podían ver matacanes en sus esquinas. Es decir seguían los modelos de otros graffiti que representaban castillos, descubiertos en contextos cristianos de los siglos XIII y XIV, como por ejemplo los del Castillo de Denia (Alicante), de Castellfollit de Riubregós (Anoia, Barcelona), del Castillo de Coaner (Sant Mateu del Bages, Lleida), del Castillo de los Calatravos de Alcañiz (Teruel) o de la Torre del Trovador en el Palacio de la Aljafería (Zaragoza) (BAZZANA, LAMBLIN y MONTMESSIN, 1984; V.V.A.A., 198I; BOLOS y SÁNCHEZ, 2003; CASANOVAS Y ROVIRA, 2002; ROYO y GÓMEZ, 2002) (Fig.7).

Otros autores desde antiguo, como GómezMoreno González y recientemente Antonio Fernández-Puertas (GÓMEZ-MORENO, 1892, T.I: । 43; FERNÁNDEZ-PUERTAS, 2000: 223), opinan que la Torre de los Picos es una torre de época nazarí transformada posteriormente por los Reyes Católicos. Esta transformación formaba parte de un programa constructivo más amplio que se desarrollaba por entonces en ese sector, con obras como el baluarte que protege el acceso a la Puerta del Arrabal y la Puerta de Hierro, sobre la que campea el escudo de los Reyes Católicos. Remodelaciones tras la 
conquista castellana también sufrieron torres nazaríes de la costa granadina y de tierras del interior, añadiéndoseles matacanes sobre ménsulas o canes, como por ejemplo la Torre de Cerro Gordo, la Torre de Almuñecar, la Torre de Cambrón y la torre-puerta del recinto amurallado que rodea la Villa de Moclín, que se transformó en torre del homenaje (MALPICA, 1996: $315,317,319,242)$.

A falta de que se realice un estudio a fondo de la Torre de los Picos, algo sí que podemos concretar, y es que con independencia de la cronología que se le asigne, todos los autores que la han estudiado, la consideran una obra ajena a la tradición nazarí y de clara inspiración cristiana.

Por todo lo dicho hasta ahora, no es descabellado pensar que nuestros graffiti sean obra de alarifes o maestros posiblemente cristianos, cautivos o no, que participaron en la construcción de la antigua torre atribuida por la bibliografía tradicional a Ismail I, o quizás durante las obras de la actual Torre de Comares, trazando en sus enlucidos el alzado de una torre de clara tradición cristiana, similar a la Torre de los Picos y a otras tantas referidas en el texto, que se construyeron en el siglo XIV.

\section{CONCLUSIÓN}

Para finalizar, tan sólo incidir un poco más en todo lo que anteriormente hemos dicho. Exponemos de manera resumida las principales razones, desarrolladas en el texto, que nos hacen pensar que los graffiti que estudiamos, son obra de verdaderos alarifes musulmanes o maestros cristianos, conocedores de las técnicas empleadas en el oficio de levantar edificios, que participaron en las referidas obras.

El empleo del compás en el trazado de nuestros graffiti, aunque ya era conocido su uso en la Alhambra en otros oficios como el de diseñar zócalos o yeserías, ahora es utilizado también en el alzado de edificios a modo de rudimentarios planos de arquitectura. Son explicaciones básicas dejadas por miembros de otro gremio, por los encargados de levantar edi- ficios. En este caso tal vez hablemos de esos alarifes o maestros referidos en las fuentes escritas. Tanto los encargados de diseñar zócalos y yeserías como estos, empleaban una misma técnica geométrica, basada en el trazado de una trama cuadriculada para posteriormente insertar motivos decorativos unos y elementos arquitectónicos otros.

La inusual representación de castillos en la iconografía hispanomusulmana, frente a los numerosos ejemplos existentes en contextos cristianos, ya sean como graffiti, decorando cerámicas, como motivos heráldicos, en pinturas murales, en yeserías, etc., nos induce a adjudicar una autoría cristiana a los graffiti localizados. La torre representada, es claramente una construcción cristiana que tiene su más cercano paralelo en la Torre de los Picos, conociéndose numerosos ejemplos de torres del siglo XIV con características similares, pero siempre en contextos cristianos. A pesar de que el debate siga abierto respecto a la cronología de la Torre de los Picos, su influencia cristiana es patente.

No sólo conocemos por los graffiti localizados en la muralla nazarí del Albayzín y por los poemas de Ibn al-Yayyab e Ibn Zamrak en yeserías de la Alhambra, de tiempos de Yúsuf I y de su hijo Muhammad $\mathrm{V}$, la participación de cautivos y/o artesanos cristianos en la construcción de murallas, torres y palacios, sino que parece tratarse de una práctica constante a lo largo de la historia de al-Andalus. Así pues, tenemos noticias tempranas de la utilización de cautivos cristianos como peones en la ampliación de la Mezquita de Córdoba realizada en tiempos de Almanzor (OCAÑA, 1986: 66), y a través de los Miráculos romançados de Pero Marín conocemos abundantes noticias del siglo XIII sobre la existencia de cautivos cristianos en Granada y en otras tantas poblaciones del reino, así como de su empleo en oficios de la construcción, como levantar tapias, labrar piedra o enlucir con yeso (COSSIO, 1942: 81).

En tiempos de Ismail I, los monarcas de Tremecén (Argelia), Abu Hammu I (I308-1318) y su hijo Abu Tasufin (1318-1337) solicitaron a aquel, artesanos y arquitectos para la cons- 
trucción de palacios en su reino, solicitud que fue contestada por el monarca granadino enviando a sus mejores arquitectos. Sobre estas obras refiere Ibn Jaldun: "Dedicó a estas obras millares de obreros, carpinteros, cerrajeros, pintores y de otros oficios, todos ellos prisioneros de guerra cristianos" (TORRES, 1946: 187). Dada esta costumbre, podemos pensar también en el posible empleo de cautivos cristianos como obreros, en las obras que se desarrollaban en la Alhambra en tiempos de Ismail I, al que la bibliografía tradicional le atribuye la construcción de esa antigua torre que soporta nuestros graffiti.

Considerando otras posibilidades, quizá la torre representada en el graffiti, fue realizada por alarifes musulmanes a la manera de los cristianos, tal y como refirió Ibn Jaldun, criticando a los habitantes de al-Andalus que gustaban de decorar los muros de sus casas con figuras y edificios tomados de los cristianos. En esta misma línea y en relación a esas influencias cristianas, irían los comentarios de Ibn alJatib sobre el famoso arquitecto Muhammad al-Hayy al-Isbili, mudéjar sevillano emigrado al norte de África tras la conquista de su ciudad por Fernando III. Nos dice que durante el tiempo que éste estuvo en la corte de Muhammad II (1273-130 I), "como de niño había vivido en territorio reconquistado estaba profundamente impregnado por la cultura y las costumbres occidentales y los granadinos le reprochaban su preferencia por las opiniones de los cristianos españoles (al-Rum) y que llegase su rebajamiento hasta imitarles en la manera de comer, de hablar y en otras muchas cosas, entre ellas el salpicar sus conversaciones con refranes y sentencias del mismo origen" (TORRES, 1946: I85). Tal vez esas mismas influencias cristianas incidieron igualmente en el terreno profesional de este arquitecto musulmán y quizás en sus diseños arquitectónicos.

En nuestro caso, los motivos estudiados no responden a una decoración mural, sino que aluden claramente al modo de construir un tipo de torre con unas características concretas. Modo de construir, que tal vez, aún se regía por ciertas normas arquitectónicas de clara influencia cristiana que tuvieron gran difusión a lo largo del siglo XIII en el mundo nazarí (visi- bles en la Alcazaba de la Alhambra) y que obedecían "a las relaciones y dependencias de los primeros nazaríes con el feudalismo castellano" (ACIÉN, 1995: 40).

Para terminar, decir tan sólo que con los graffiti presentados en este breve estudio, se amplia un poco más el corpus de motivos conocidos hasta ahora en nuestra ciudad. Un patrimonio histórico y cultural ignorado por muchos y tan necesario de salvaguardar.

\section{BIBLIOGRAFÍA}

ABELLÁN PÉREZ, J. ( 1982): "El graffiti medieval de la Iglesia Parroquial del Divino Salvador de Vejer de la Frontera", Estudios de Historia y Arqueología. II, pp. I37-140.

ACIÉN ALMANSA, M. (1995): "La fortificación en alAndalus", en R. López Guzmán, La arquitectura del Islam occidental. Barcelona, pp. 29-4I.

BARCELÓ, C. (1989): "IV. Los epígrafes árabes de Guardamar", en R. Azuar Ruiz, La Rábita Califal de las Dunas de Guardamar (Alicante). Alicante, pp. I83-197.

BARRERA MATURANA, J. I. (2002): "Graffiti en la muralla del Albayzín", Arqueología y Territorio Medieval. 9, pp. 289-328.

BARRERA MATURANA, J. I. (2003): "Los graffiti de la muralla islámica de Granada", I Congrés Internacional de Gravats Rupestres i Murals, Lleida 1992. Lleida, pp. 721733.

BARRERA MATURANA, J. I. (2004): "Participación de cautivos cristianos en la construcción de la muralla nazarí del Albayzín (Granada): sus graffiti", Arqueología y Territorio Medieval. II.I, pp. 125-158.

BARRERA MATURANA, J. I. (en prensa): "Nuevos graffiti en Madinat al-Zahra", Cuadernos de Madinat al-Zahra.

BARRERA MATURANA, J. I. y CRESSIER, P. (2003): "Grabados parietales y rupestres de Almería: Un problema de cronología", I Congrés Internacional de Gravats Rupestres i Murals, Lleida 1992. Lleida, pp. 709-720.

BARRERA MATURANA, J. I., CRESSIER, P. y MOLINA MUÑOZ, J. A. (1999): "Garabatos de alarifes: Los graffiti de las galerías de desagüe de Madinat al-Zahra", Cuadernos de Madinat al-Zahra. 4, pp. 39-8I.

BAZZANA, A., LAMBLIN, M. P. y MONTMESSIN, Y. (1984): Los graffiti medievales del Castell de Denia. Catálogo. Denia (Alicante).

BOLOS, J. y SÁNCHEZ, I. (2003): "Els grafits medievals de la torre de Coaner (el Bages)", I Congrés Internacional de Gravats Rupestres i Murals, Lleida 1992. Lleida, pp. 765776. 
CABANELAS RODRÍGUEZ, D. (1988): El techo del Salón de Comares en la Alhambra. Decoración, policromía, simbolismo y etimología. Granada.

CASANOVAS ROMEU, A. y ROVIRA PORT, J. (2002): "Los graffiti medievales y post-medievales del Alcañiz monumental", Al-Qannis, Boletín del Taller de Arqueología de Alcañiz. 9, pp. 5-54.

CASARES LÓPEZ, M. (1973): "Documentos sobre la Torre de Comares", Cuademos de la Alhambra. 9, pp. 53-66.

CONTRERAS, R. (1878): Estudio descriptivo de los monumentos árabes de Granada, Sevilla y Córdoba, o sea la Alhambra, el Alcázar y la Gran Mezquita de Occidente. Madrid.

COSSIO, J. M․ de (1942): "Cautivos de moros en el siglo XIII", Al-Andalus. VII, pp. 49-II 2 .

CRESSIER, P. (1986): "Graffiti cristianos sobre monumentos musulmanes de la Andalucía Oriental: Una forma de exorcismo popular", I Congreso de Arqueología Medieval Española, Huesca 1985. T. I, Zaragoza, pp. 273-29I.

FERNÁNDEZ-PUERTAS, A. (2002): "El arte", en Menéndez Pidal, Historia de España t. VIII-IX, "El reino nazarí de Granada (| 232-|492). Sociedad, vida y cultura". Madrid, pp. $191-284$

GÁMIZ GORDO, A. (200 I): La Alhambra nazarí. Apuntes sobre su paisaje y arquitectura. Inst. Univ. de Ciencias de la Construcción, Universidad de Sevilla, Sevilla.

GARCÍA BUENO, A., MEDINA FLORES, V. J. y LÓPEZ PERTIÑEZ, Ma. del C. (2003): "El trazado de los zócalos pintados nazaríes a partir de los restos de dibujo preparatorio: El Cuarto Real de Santo Domingo y la Alhambra de Granada", Cuadernos de la Alhambra. 39, pp. 9-36.

GARCÍA GÓMEZ, E. (1985): Poemas árabes en los muros y fuentes de la Alhambra. Instituto Egipcio de Estudios Islámicos, Madrid.

GARCÍA GRANADOS, J. A. (1987): "Técnicas nazaríes de trazado de lacería", II Congreso de Arqueología Medieval Española. T. II, Madrid, pp. 659-668.

GÓMEZ-MORENO CALERA, M. (2002): "Estructuras defensivas de la Alhambra, I. Cuestiones generales", Cuadernos de la Alhambra. 38, pp. 125-154.

GÓMEZ-MORENO GONZÁLEZ, M. ( 1892 ): Guía de Granada. Ts. I y II, Colección Archivum, Universidad de Granada, Edición 1994.

GÓMEZ-MORENO MARTÍNEZ, M. (1966): "Granada en el siglo XIll", Cuadernos de la Alhambra. 2, pp. 3-45.

GONZÁLEZ LIMÓN, T. y CASAS GÓMEZ, A. de las (1997): "Estudio de los materiales y de las fábricas de la Torre de Comares de la Alhambra", Cuadernos de la Alhambra. 33-34, pp. 95-104.

IZQUIERDO BENITO, R. (1994): La ciudad hispanomusulmana de "Vascos" Navalmoralejo (Toledo). Campañas 1983-1988. Toledo-Madrid.
MALPICA CUELLO, A. (1996): Poblamiento y castillos en Granada. Lunwerg Editores, Barcelona.

MALPICA CUELLO, A. (200I): "La Alhambra que se construye. Arqueología y conservación de un monumento", en J. A. González Alcantud y A. Malpica Cuello, Pensar la Alhambra. Barcelona. pp. 33-66.

MALPICA CUELLO, A. (2002a): "La Alhambra y su entorno: espacio rural y espacio urbano", Cuadernos de la Alhambra. 38, pp. 183-218.

MALPICA CUELLO, A. (2002b): La Alhambra de Granada, un estudio arqueológico. Colección Monográfica Arte y Arqueología, Universidad de Granada.

MENÉNDEZ PIDAL, G. (1986): La España del siglo XIII leída en imágenes. Real Academia de la Historia, Madrid.

OCAÑA JIMÉNEZ, M. (1986): "Arquitectos y mano de obra en la construcción de la gran mezquita de Occidente", Cuadernos de la Alhambra. 22, pp. 55-85.

PAVÓN MALDONADO, B. ( 1975): "El Palacio de Comares", en Estudios sobre la Alhambra Vol. I. Granada, pp. $65-114$

PAVÓN MALDONADO, B. ( 1 977): "Puertas y torres de la Alhambra (siglo XIV). La Torre de los Picos", en Estudios sobre la Alhambra Vol. II. Granada, pp. 129-I34.

RODRIGO MARHUENDA, L. Y CALANCHA DE PASSOS, J. (1990): "Conservación y restauración de las pinturas murales de la Puerta de las Armas y de la Torre de los Picos", Cuadernos de la Alhambra. 26, pp. 349-370.

ROYO GUILLÉN, J. I. y GÓMEZ LECUMBERRI, F. (2002): "Panorama general de los "graffiti" murales y de los grabados al aire libre medievales y post-medievales en Aragón", Al-Qannis, Boletín del Taller de Arqueología de Alcañiz. 9, pp. 55-। 56.

RUBIERA MATA, Ma. J. (1995): "Los textos epigráficos de los palacios nazaríes (algo más que una escritura)" en Arte islámico en Granada. Propuesta para un Museo de la Alhambra. Patronato de la Alhambra y Generalife, Granada, pp. 97-105.

RUBIERA MATA, Ma. J. (2004): "Los pájaros verdes de las rábitas de las dunas de Guardamar del Segura", LOCVS AMOENVS. 7, Dpto. Arte Univ. Autónoma de Barcelona, pp. 27-33.

RUÍZ DE LA ROSA, J. A. (1996): "La arquitectura islámica como forma controlada. Algunos ejemplos en AlAndalus", en Arquitectura en Al-Andalus. Documentos para el s. XXI. Lunwerg Editores, Madrid, pp.27-54.

RUÍZ TORRES, S. y PADIAL PÉREZ, J. (200 I): "La muralla nazarí del Albaycín: un ejemplo de los procedimientos y técnicas constructivas empleadas en la Edad Media", Revista CVDAS. 2, pp. 131-153.

SOLER, A. y ZOZAYA, J. (1992): "Castillos omeyas de planta cuadrada: su relación funcional", III Congreso de Arqueología Medieval Española, Oviedo 1989. Oviedo, pp. 265-274. 
SOUTO LASALA, J. A. (1997): "La práctica y la profesión del artista en el Islam: arquitectos y constructores en al-Andalus omeya", Espacio, Tiempo y Forma, Serie VII. I0, pp. I I-34.

SOUTO LASALA, J. A. (200 I): "Los constructores de alAndalus Omeya" en El esplendor de los Omeyas Cordobeses. La civilización musulmana de Europa Occidental. Granada, pp. 274-28I.

SOUTO LASALA, J.A. (2003): "Glyptographie omeyyade: croquis de travailleurs de la Grande Mosquée de Cordoue", Actes du XIlle Colloque International de Glyptographie de Venise. Braine-le-Château, pp. 36I-384.

TORRE LÓPEZ, Ma . J. de la (1995): Estudio de los materiales de construcción en la Alhambra. Colección Monográfica Arte y Arqueología, Universidad de Granada e Instituto Andaluz del Patrimonio Histórico, Granada.

TORRES BALBÁS, L. (1946): "Arquitectos andaluces de las épocas almorávide y almohade", Obra Dispersa. Crónica de la España Musulmana. Vol. 3, Crónica XVIII, Madrid, pp. 179-189.

TORRES BALBÁS, L. (1947): "Ajimeces", Obra Dispersa. Crónica de la España Musulmana. Vol. 4, Crónica XXI, Madrid, pp. II-29.

TORRES BALBÁS, L. (1952a): "Actividades de los moros burgaleses en las artes y oficios de la construcción (siglos XIII-XV)", Obra Dispersa. Crónica de la España Musulmana. Vol. 5, Crónica XXXIV, Madrid, pp. 303-308.

TORRES BALBÁS, L. (1952b): "Las torres de El Carpio (Córdoba) y Porcuna (Jaén)", Obra Dispersa. Crónica de la España Musulmana. Vol. 5, Crónica XXX, Madrid, pp. |20- 143.
TORRES BALBÁS, L. (1952c): "Leonardo de Vinci y las bóvedas hispano-musulmanas", Obra Dispersa. Crónica de la España Musulmana. Vol. 5, Crónica XXXI, Madrid, pp. 197-203.

TORRES BALBÁS, L. (1959): "El baño de Doña Leonor de Guzmán, en el Palacio de Tordesillas", Obra Dispersa. Crónica de la España Musulmana. Vol. 7, Crónica XLV, Madrid, pp. 63-85.

VALLE FERNÁNDEZ, T. y RESPALDIZA LAMA, P. . . (2000): "La pintura mural almohade en el Palacio del Yeso", Apuntes del Alcázar de Sevilla. (Edición digital), I, Mayo, pp. 56-73.

VELÁZQUEZ BOSCO, R. (1912): Arte del Califato de Córdoba. Medina Azzahra y Alamiriya. Madrid.

VÍLCHEZ VÍLCHEZ, C. (1988): La Alhambra de Leopoldo Torres Balbás (Obras de restauración y conservación $1923-$ 1936).Granada.

VILLENA, L. (1987): "Sobre la terminología comparada de los elementos fortificativos", II Congreso de Arqueología Medieval Española. T. II, Madrid, pp. 303-3I8.

VIÑES MILLET, C. (1982): La Alhambra de Granada. Monte de Piedad y Caja de Ahorros de Córdoba, Córdoba.

V.V.A.A. (1981): "Los grafitos de Castellfollit de Riubregós. Primeras aportaciones", Quaderns d'estudis medievals. II, 5, pp. 278-310. 




Fig. I. Situación de los graffiti en el adarve subterráneo de la Torre de Comares.

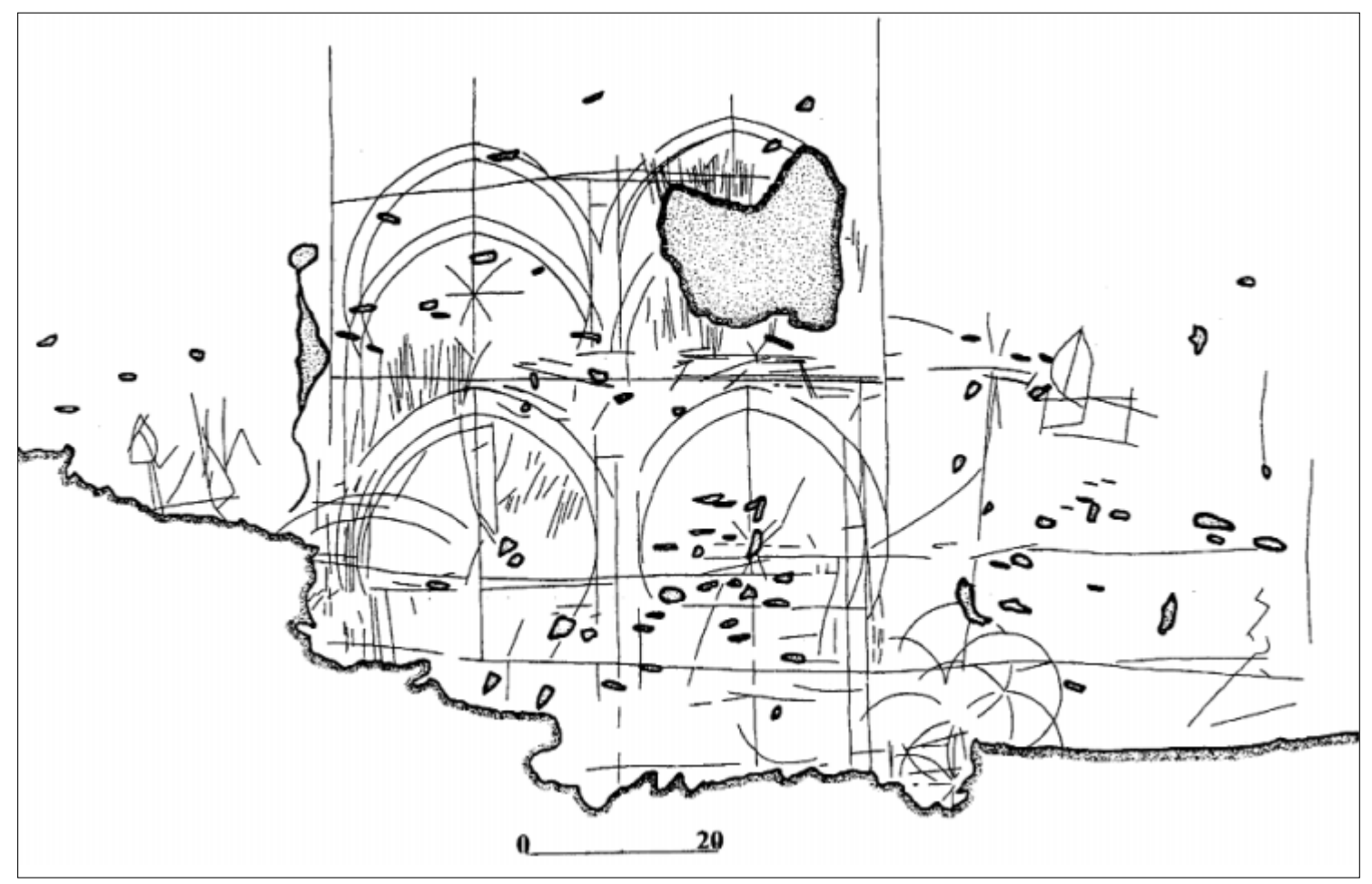

Fig. 2. Graffiti que constituyen el Conjunto A. 


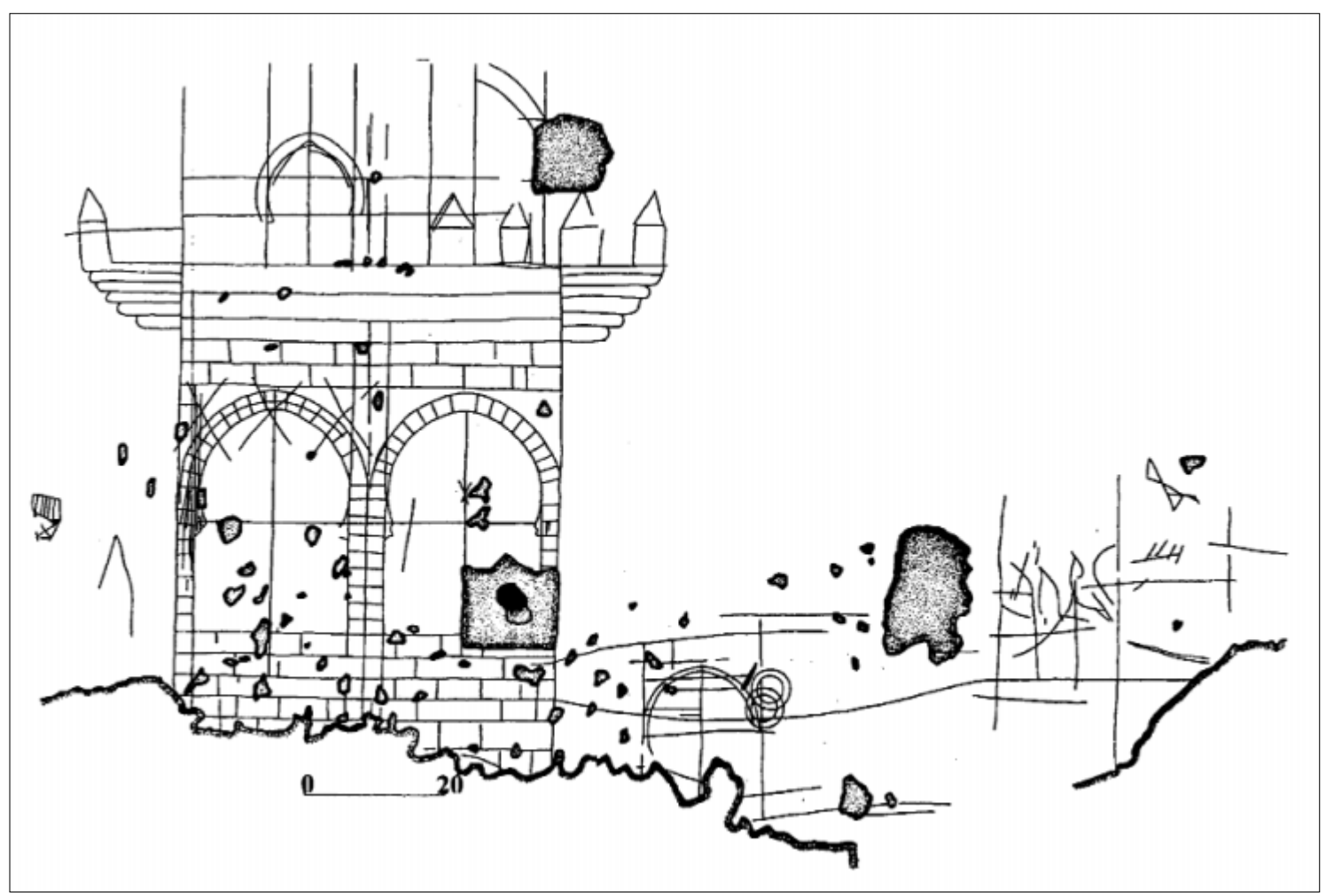

Fig. 3. Graffiti que constituyen el Conjunto $B$.

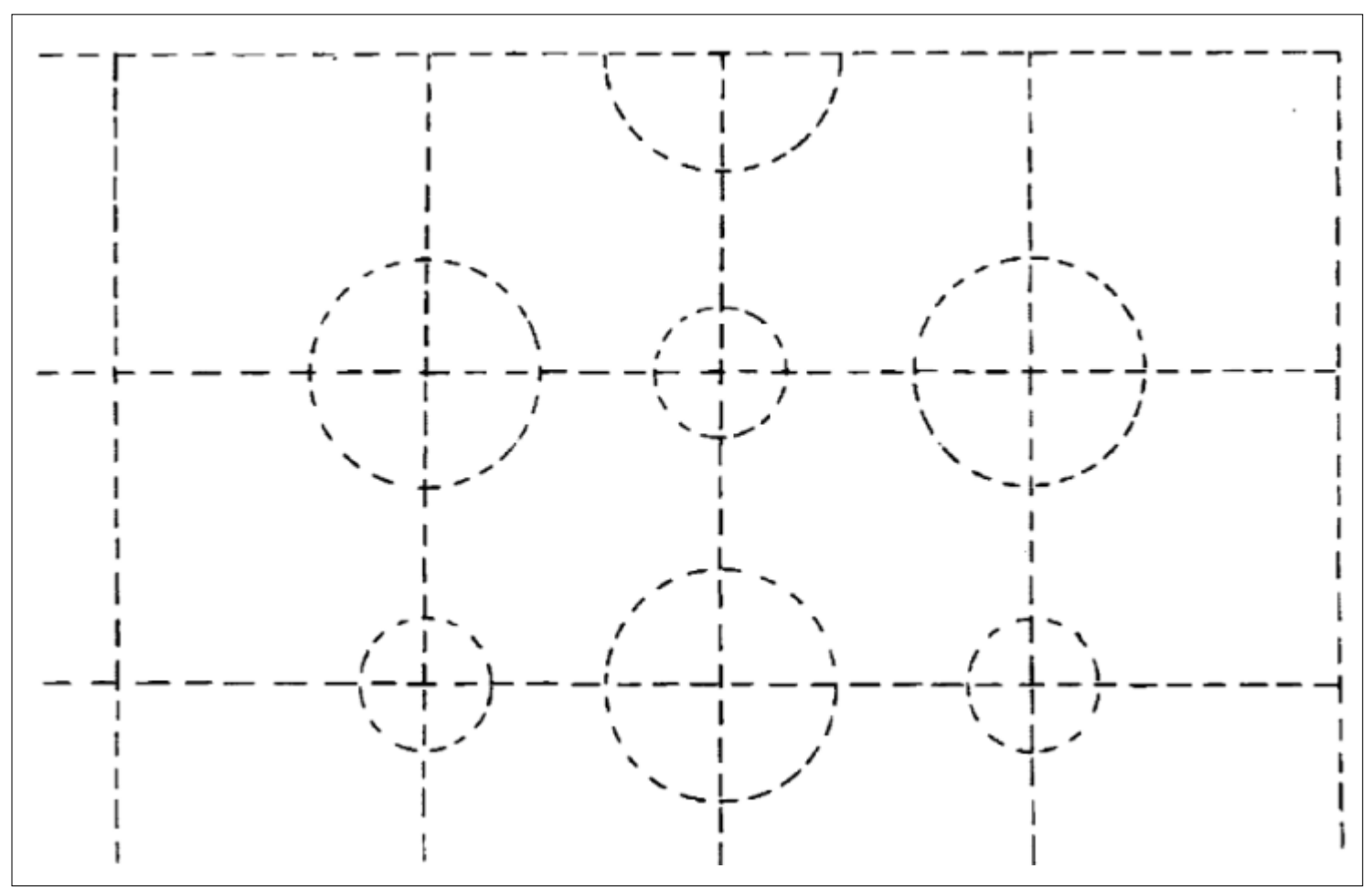

Fig. 4. Trama cuadriculada de zócalo en el Peinador Bajo de la Alhambra (García Bueno, et alii, 2003). 




Fig. 5. Diversos detalles de los graffiti. 


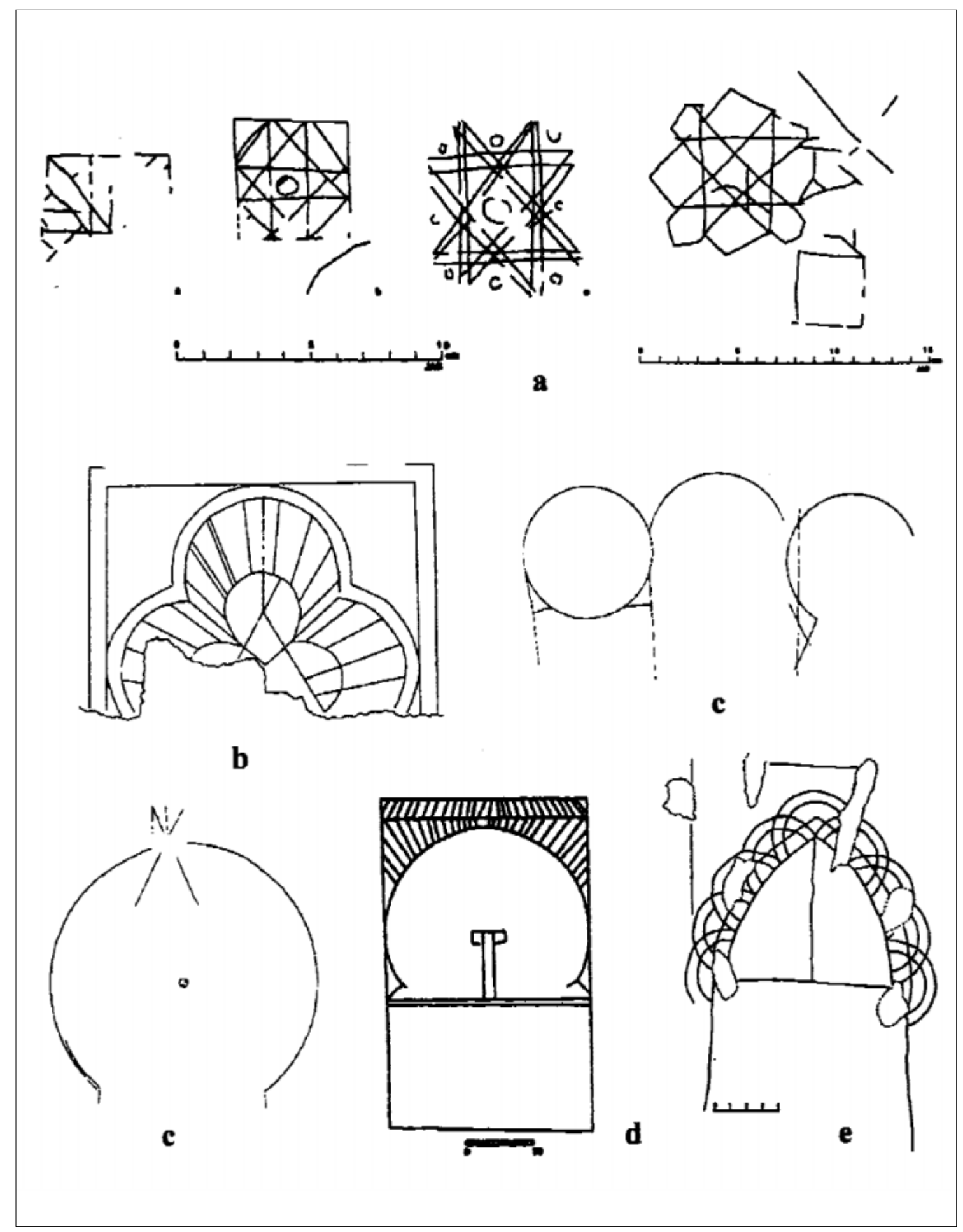

Fig. 6. Graffiti que representan diseños arquitectónicos, a: Mezquita de Córdoba; b y c: Madinat al-Zahra (Córdoba); d: Muralla nazarí del Albayzín (Granada); e: Iglesia del Divino Salvador de Vejer de la Frontera (Cádiz). 



c
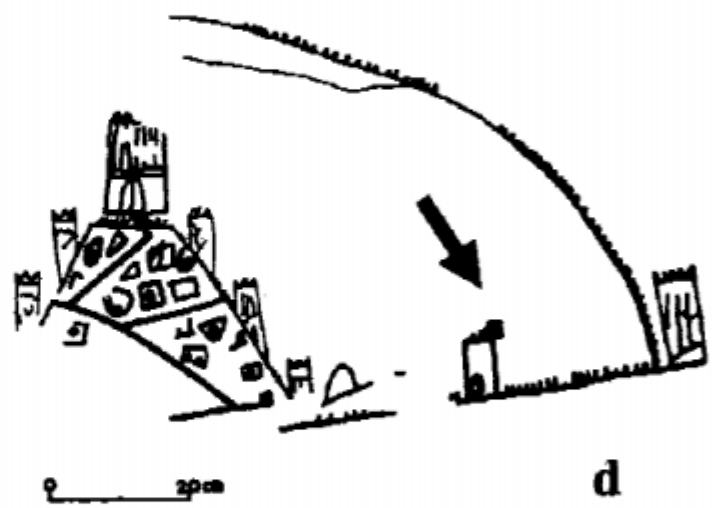

d
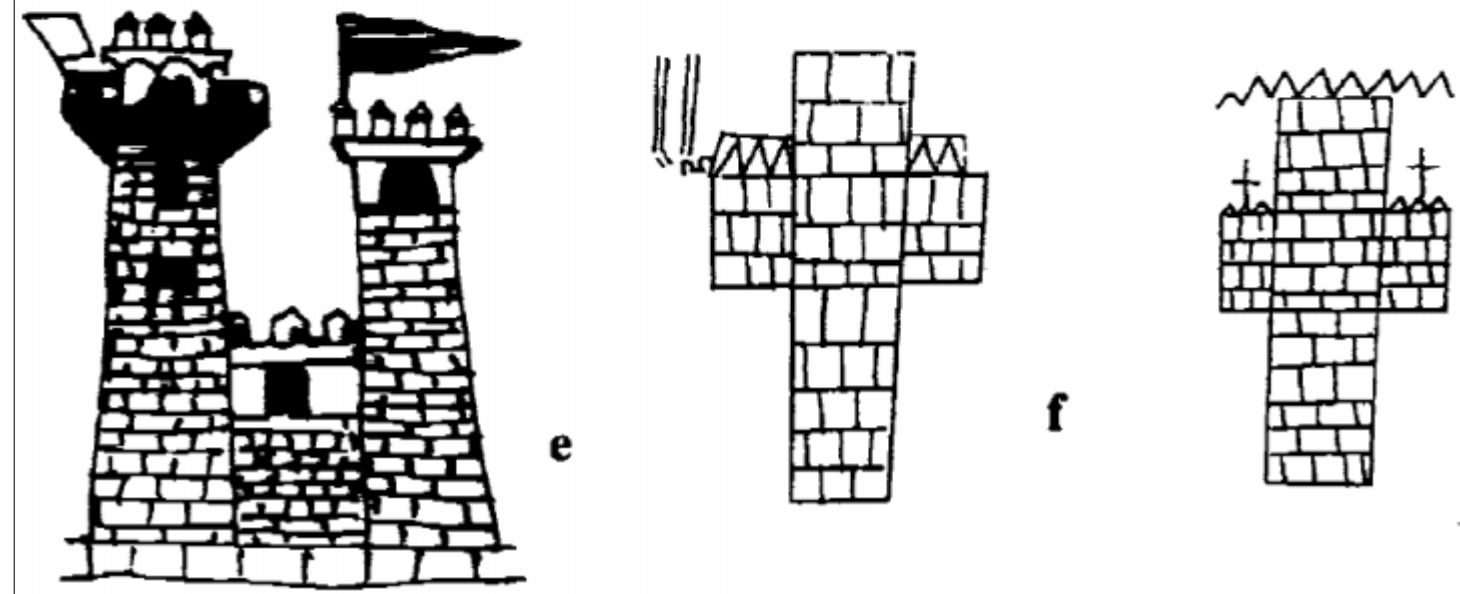

Fig. 7. Graffiti que representan matacanes, a y b: Castellfollit de Riubregós (Anoia, Barcelona); d: Muralla nazarí del Albayzín (Granada); f: Torre del Trovador en el Palacio de la Aljafería (Zaragoza). Imágenes de matacanes, c: llustración de las Cantigas de Alfonso X el Sabio; e: Pintura mural del Castillo de los Calatravos de Alcañiz (Teruel). 


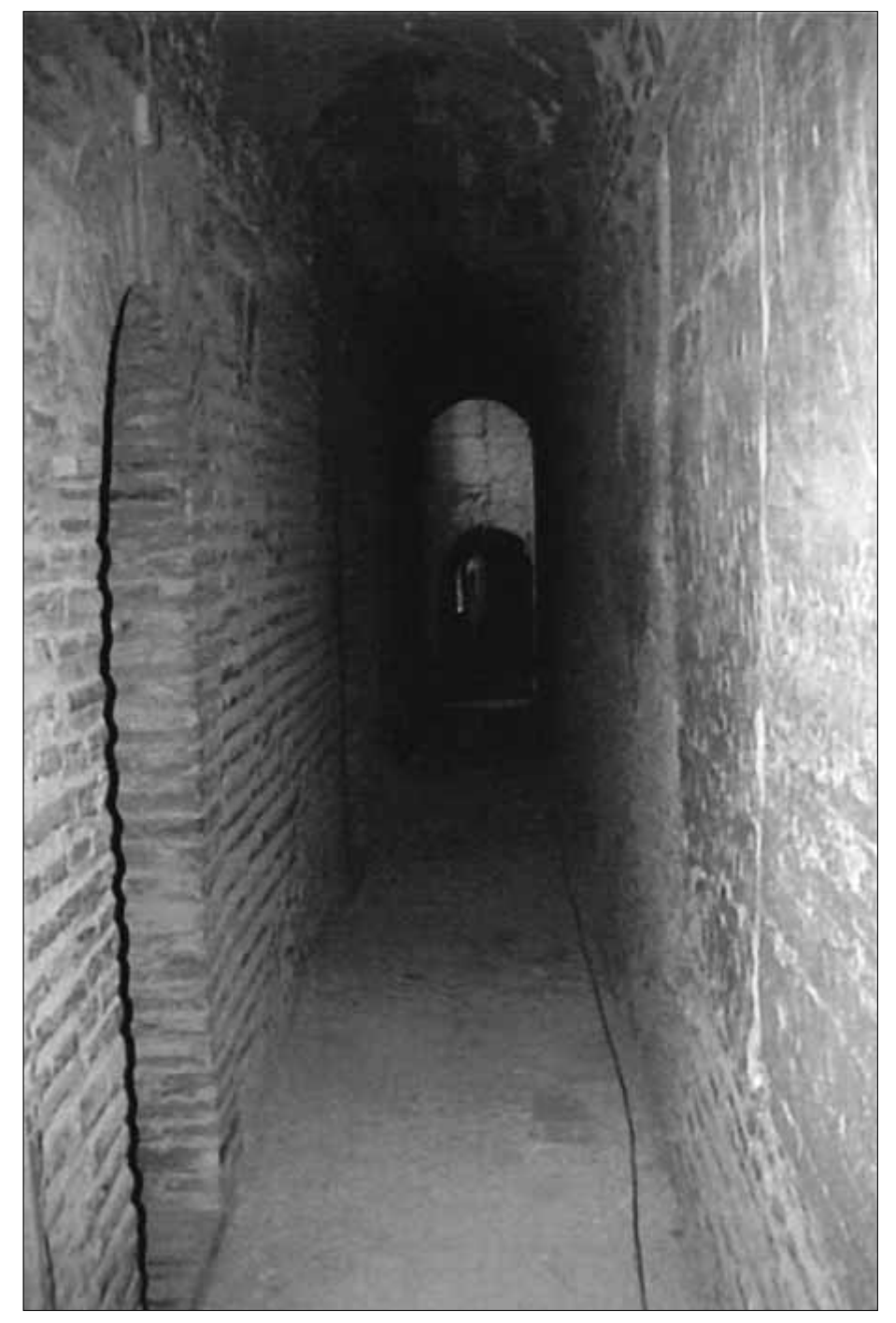

Lam. I. Adarve subterráneo

de la Torre de Comares.

Lam. 2. Zócalo en el Peinador Bajo de la Alhambra.






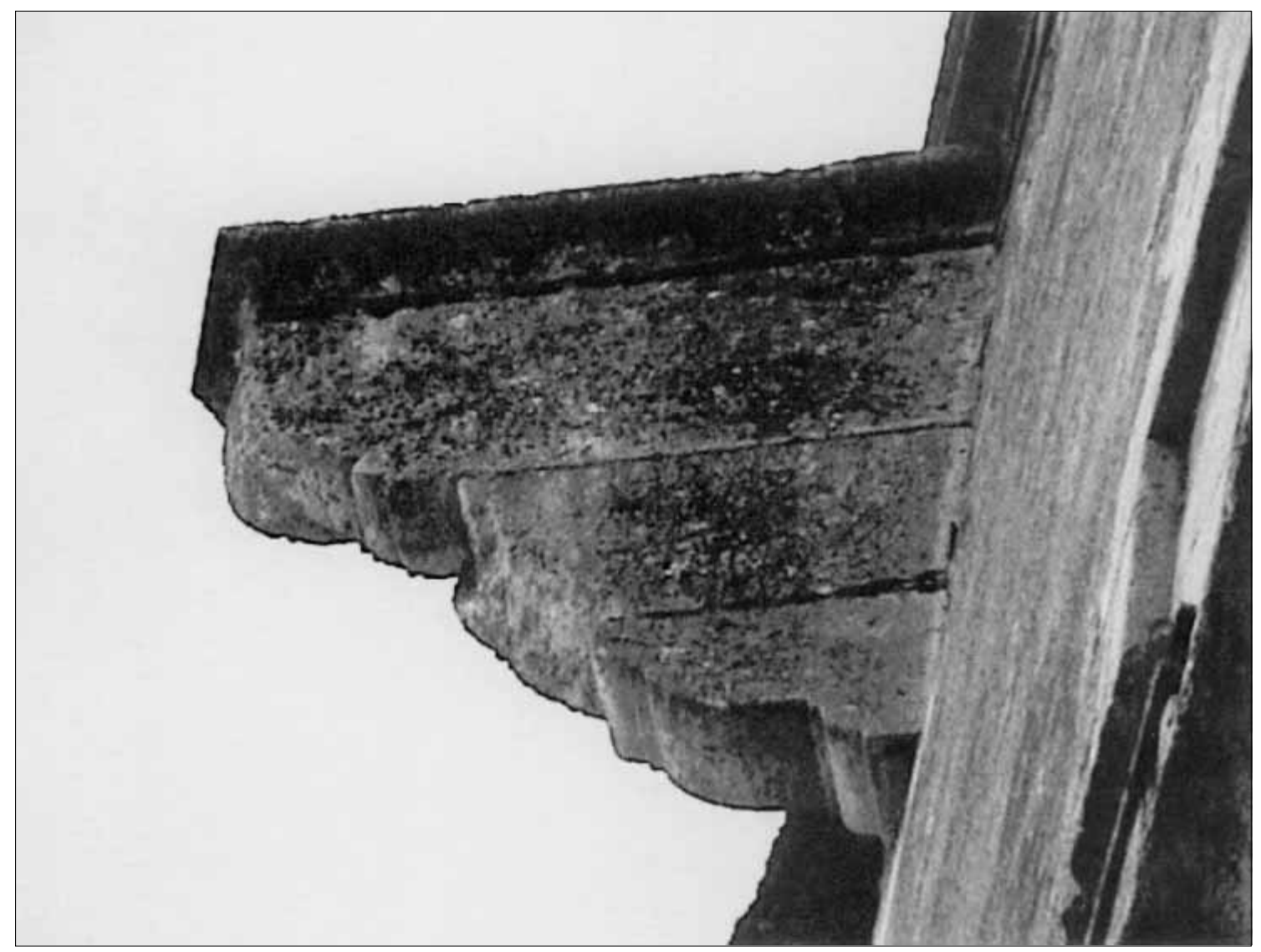

Lam. 3. Ménsula de matacán en la Torre de los Picos.

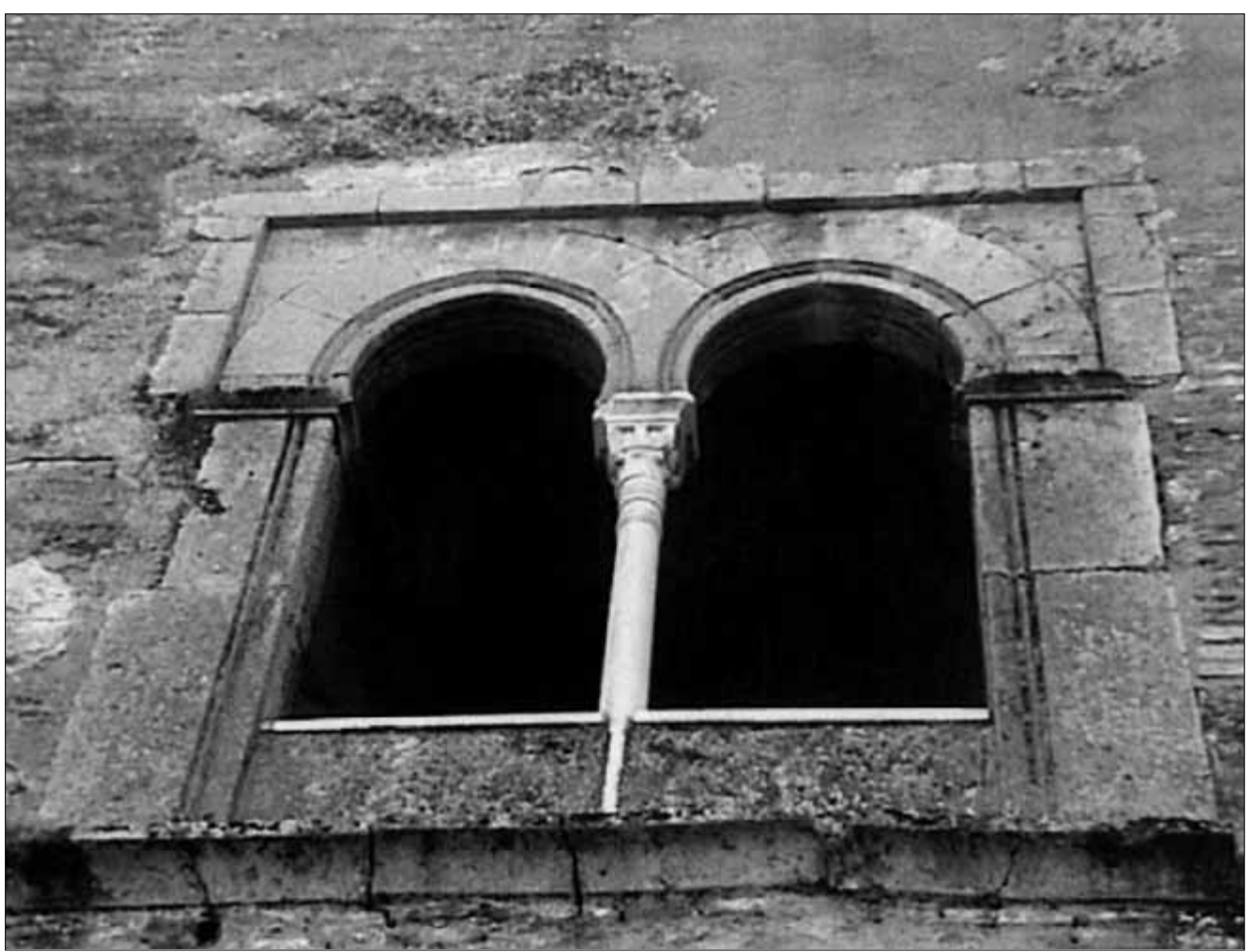

Lam. 4. Ventana de la Torre de los Picos. 


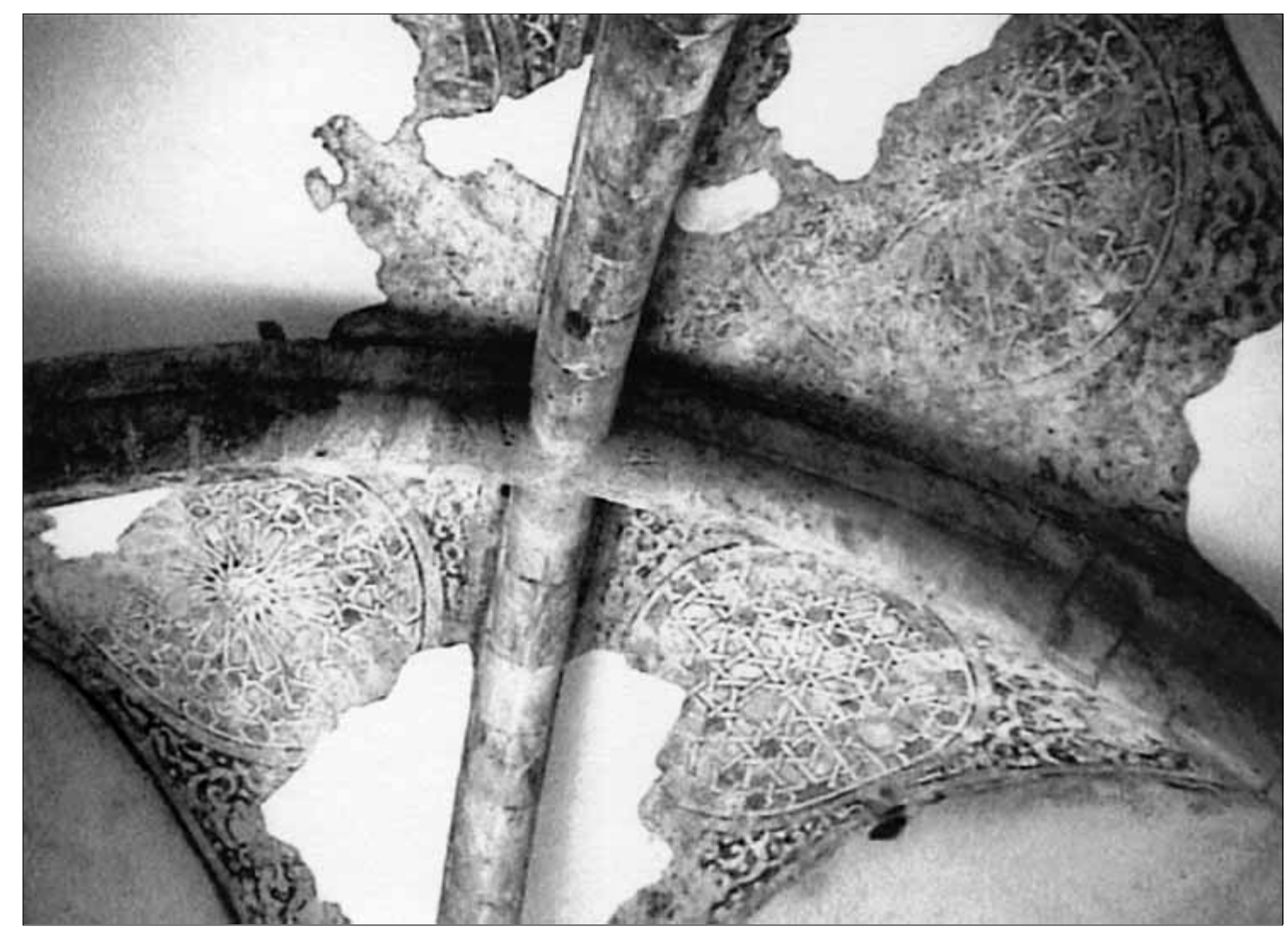

Lam. 5. Bóvedas de la Torre de los Picos.



Lam. 6. Torre de los Picos. 